\title{
The Strength of Moulding Sand Consisting of a Mixture of Bentonite, Tapioca Flour, and Sago Flour as a New Binder Formula to Improve the Quality of Al-Si Cast Alloy
}

\author{
Andoko ${ }^{1}$, Riana Nurmalasari ${ }^{1}$, M. Alfian Mizar ${ }^{1}$, Retno Wulandari ${ }^{1}$, Poppy Puspitasari ${ }^{1}$, Avita Ayu \\ Permanasari $^{1}$ \\ ${ }^{1}$ Department of Mechanical Engineering, Faculty of Engineering, Universitas Negeri Malang, Semarang Street No. 5, \\ Malang, East Java, Indonesia \\ Corresponding author: *andoko.ft@um.ac.id
}

\begin{abstract}
The major factors determining the quality of sand casting products are the base sand and the composition of the sand mould and the binding material. In the foundry industry, the most commonly used binder for creating sand moulds is bentonite. However, the price of bentonite is likely to keep rising. This study aimed at discovering a new binder formula associated with the effect of binder composition i.e. bentonite, tapioca flour, and sago flour on the basis of its mechanical and physical properties. The new formula was expected to be a better binder in the production of sand moulds, resulting in high-quality casting products with minimal defects. Moreover, it is probable to be much more economical than bentonite. This research focused on testing the moulding sand composition with a number of different binders, i.e. bentonite, tapioca flour, and sago flour, each in a different proportion. The mixture of the moulding sand with each of the three binders will be tested in terms of its mechanical properties including compressive, shear, and tensile strength. Based on the test results, sago flour has the highest dry compressive strength of $28.6 \mathrm{~N} / \mathrm{cm} 2$, whereas bentonite has the highest wet compressive strength, i.e. $11.83 \mathrm{~N} / \mathrm{cm} 2$ and the highest wet shear strength i.e. $3.16 \mathrm{~N} / \mathrm{cm} 2$. The binder with the highest dry shear strength is tapioca flour with $18.16 \mathrm{~N} / \mathrm{cm} 2$. Regarding the tensile strength value, bentonite has the highest wet tensile strength of $0.85 \mathrm{~N} / \mathrm{cm} 2$, while sago flour has the highest dry tensile strength of $1.73 \mathrm{~N} / \mathrm{cm} 2$..

Copyright (C) 2017Journal of Mechanical Engineering Science and Technology All rights reserved

Keywords: Moulding sand, Bentonite binder, Tapioca flour, Sago flour
\end{abstract}

\section{Introduction}

Rapid technological development has influenced an increased demand for productions, one of which utilises aluminium. As stated by [1], aluminium has been used in a wide variety of products ranging from household furniture to aircraft industry. [2] pointed out that aluminium is lightweight metal with good corrotion resistance. In addition to its corrotion resistance, low density, and good electrical conductivity, aluminium will posses superior physical and mechanical properties if it is combined with certain elements [3]. Some of those properties have made aluminium the most commonly used material in production industry.

One of the production processes utilising aluminium is metal casting. Metal casting is the most important initial process in metal industry [4]. The casting process is performed by melting metals in the melting furnace, pouring it into a mould, and allowing it to solidity until it can be removed from the mould. [5] stated that metal casting is a process in which metals are melted into liquid at a certain temperature, and then poured into the mould prepared beforehand to form the desired shape.

Casting systems and processes cannot be separated mould. In general, sand mould is the most popular among others types of moulds [6]. In manufacturing sand moulds, the sand is undergone a process of compaction [7]. Moulding sand is formed from a mixture of sand, binder and other additional materials. Moulding sand is the most frequently used component in metal casting process due to its low production cost, reusability, thermal resistance, ease of operation, and acceptable quality [8]. Sand mould casting process is carried out through several stages. The initial stage is placing pattern in the sand to form a mould cavity; molds are usually prepared by compressing the sand [6]. The next stages are as follows: creating a gating system, pouring molten metal into the mould, allowing the molten metal to solidify, breaking up the mould and removing the casting, and cleaning the casting product [8]. 
The process of metal casting is always associated with defective castings. A number of casting defects commonly occurred are uneven surface hardness, porosity and other defects caused by a collapsed mould. The major cause of defects in the casting process is the properties of the mould, such as low permeability, low compressive strength, low sintering point, and inappropriate sand grain distribution [9]. Furthermore, mould might affect the metal hardness and shape [4]. It is in line with [1] who stated that there are many factors influencing sand casting products, some of which are the composition of the mould and the design of the gating system; they should be meticulously determined to prevent the occurrence of defects and to obtain optimum casting products.

Green sand casting is known for its low-cost production. However, due to its low-strength mould, casting defects can be found mostly in the products of green sand casting in which clay is used as the binder. In order to avoid the aformentioned shortcoming, dry sand can be used as a possible alternative, but it takes a long time for the casting to completely dry. Thus, as an attempt to produce a mould that can dry up a short time, this following step can be taken, i.e. by utilising a type of binder which has no drawbacks such as the emergence of gas defects, bad fire resistance, costly production, and complex mold production process. Several materials that can be used as special binders are water-glass, resin, cement, flour, and many more [10]. Binder, as a vital element in the composition of sand moulds, will affect the quality of casting products [11].

In the present study, the researchers combined bentonite with two types of flour, i.e. tapioca flour and sago flour, as a binding agent of the moulding sand.

This mixture was expected to generate a binder formula with a high level of binding that can minimise any potential defects in the casting products. The casting method employed was gravity casting due to the fact that it is a relatively easy and uncomplicated method since molten metal can be transferred into the entire extremities of the mould cavity only by the force of gravity [12-16]. Moreover, gravity casting produces succesful castings [17].

There has been a multitude of researches on the composition of moulding sand, one of which was conducted by [18]. Through his research, [18] found that the amount of moulding sand had an impact on the surface of the aluminium casting products which could be seen from the level of surface roughness. Another research, conducted by [19], showed that the level of clay contained in the moulding sand significantly affected the smoothness and the tensile strength of the casting products. [20] further pointed out that there was a difference in the permeability of mixtures containing various amount of water; the optimum permeability of a mixture containing $10.5 \%$ water was $0.233 \mathrm{gr} /(\mathrm{cm} 2 / \mathrm{min})$. In addition, there was an effect of different amount of water to the compressive strength; optimum compressive strength obtained from a mixture containing $9 \%$ water was $0.619 \mathrm{kN} / \mathrm{cm} 2$. There was an impact of the various amount of water in the mixture of green sand and bentonite on the permeability and the compressive strength of the moulding sand. The mixture of green sand with bentonite consisting $10 \%$ water resulted in the most optimum permeability of $54.63 \mathrm{~cm} 3 / \mathrm{min}$ and the compressive strength of $50.25 \mathrm{kN} / \mathrm{m} 2$.

In addition to researches on the composition of moulding sand, there have been a number of previous researchers on the various types of moulding sand. One example was carried out by [21] who analysed the properties of green sand (silica sand, bentonite and water), molasses sand (silica sand, bentonite and molasses), and river sand (river Ceper sand and water). The findings suggested that green sand had the highest permeability of $19.5 \mathrm{~cm} 3 / \mathrm{min}$, whereas river sand had the lowest permeability of $1.5 \mathrm{~cm} 3 / \mathrm{min}$. The sand with the highest percentage of graphite was molasses sand with $24.6 \%$, while the lowest was river with $16.26 \%$. Based on the measurement of graphite, green sand had the longest graphite particles with $79.7 \mu \mathrm{m}$, whereas river sand has the shortest with 31.38 $\mu \mathrm{m}$. In terms of the void quantity, the highest number was in river sand (0.65\%) and the lowest was in green sand $(0.47 \%)$. Furthermore, the matrix structure of green sand was ferritic while molasses sand was pearlitic. Green sand had the highest binding tension of $1.59 \mathrm{~N} / \mathrm{m} 2$, but the lowest hardness of $89.42 \mathrm{HRB}$. On the other hand, molasses sand had the lowest of $1.43 \mathrm{~N} / \mathrm{m} 2$ but the highest hardness $93.8 \mathrm{HRB}$. The surface of the casting product made of molasses sand was soft and bright, whereas the one made of river sand was rough and dark. Despite those distinctive properties, the three kinds of moulding sand possessed the same impact strength of $0.050 \mathrm{~J} / \mathrm{mm} 2$. The macro images of each specimen showed that they displayed relatively the same fracture.

Referring to the previous study on fluidity conducted by [28], it was suggested that the higher the pouring temperature and the thicker the casting is, the longer the fluidity is. This study examined the 
effect of pressure to fluidity on ADC 12 using High Pressure DieCasting technique. The testing on fluidity was undertaken by employing Birmingham method and by means of several moulds in the form of plates with different thickness.

Next, [13] has conducted a study on how the amount of bentonite contained in the moulding sand affects the surface evenness of the casting products and the tendency for aluminium defects. The finding of the micro structure test showed that the casting product with the smallest surface defect is the one made of a mould containing $8 \%$ of bentonite. The casting product made of Malang sand and containing $10 \%$ of bentonite displayed a number of defects: misrun and cold shut (causing molten metal unable to completely fill the mould cavity), sand inclusion, blow hole, pin hole, crush or drop (causing the form of fins, swells, and casting with inaccurate pattern), shrinkage, mould erosion, and rat tail.

\section{Method}

The design of this current study is pre-experimental, namely one-shot case study. The necessary data in the test of moulding sand's compressive, shear, and tensile strength, and permeability was obtained by examining Malang sand in which binding matterials had been added. Each sample was duplicated three times. The testing samples have complied with with SNI 15-0312-1989. Several instruments to collect the necessary data were sand rammer, universal strength machine, electrical scale, and heater.

The data analysis technique used in this research is descriptive analysis, which sheds light on the comparison of three groups of moulding sand specimens, each of which was given different binder in the process of moulding sand testing. The strength value of each group was averaged out, and the results were compared to the other groups. Then, the comparison results of each moulding sand testing were analysed.

\section{Results and discussion}

The tests in this study have revealed that bentonite has the highest wet compressive strength of $11.83 \mathrm{~N} / \mathrm{cm} 2$ and sago flour has the highest dry compressive strength of $28.6 \mathrm{~N} / \mathrm{cm} 2$. There have been several notable researches that offer support for these findings. The research conducted by [22], for instance, showed that the addition amount of bentonite affected the compressive strength; the more bentonite was used, the higher compressive strength would be. This happened because an increased amount of bentonite would increase the production of silicon dioxide ( $\mathrm{SiO} 2$ ) as well. Next, [4] argued that the amount of bentonite influenced the level of permeability and compressive strength. The more bentonite was added to the mixture of sand, the more pores within the sand grains were filled, resulting in a decreased permeability and an increased compressive strength. [22] further pointed out in his research that there was an effect of the rise in the amount of bentonite on higher compressive strength. The lowest compressive strength of the specimen Type A without bentonite was $15.47 \mathrm{KN} / \mathrm{m} 2$ or $157.750 \mathrm{gr} / \mathrm{cm} 2$. The explanation of this finding is that if there is no addition of silicon dioxide ( $\mathrm{SiO} 2)$ to the moulding sand, then the compressive strength will be decreasing. The lowest compressive strength of the specimen Type D with 70 gr of bentonite was $74.57 \mathrm{KN} / \mathrm{m} 2$ or $760.405 \mathrm{gr} / \mathrm{cm} 2$. In other words, the more bentonite was, the more silicon dioxide ( $\mathrm{SiO} 2)$ would be generated and hence the higher compressive strength.

In metal casting industry, one of the top priorities is managing the cost of production in order to produce high-quality castings at minimum costs. [6] argued that not only the base sand but the binding agent should be reasonably priced to minimise the production cost. Bentonite is a binder which has the highest wet compressive strength but relatively costly. One viable alternative the researcher suggested is the use of a mixture of bentonite, tapioca flour, and sago flour. This mixture has $6.7 \mathrm{~N} / \mathrm{cm} 2$ of compressive strength, which has fulfilled the acceptable standard i.e. $3.45-15.17$ $\mathrm{N} / \mathrm{cm} 2[23]$. 
Table 1. Results of Comparing Wet Compressive Strength and Dry Compressive Strength

\begin{tabular}{ccc}
\hline Binder & $\begin{array}{c}\text { Wet compressive strength } \\
\left(\mathbf{N} / \mathbf{c m}^{\mathbf{2}}\right)\end{array}$ & $\begin{array}{c}\text { Dry compressive strength } \\
\left(\mathbf{N} / \mathbf{c m}^{\mathbf{2}}\right)\end{array}$ \\
\hline Bentonite & 11.83 & 12.16 \\
\hline Tapioca Flour & 5.06 & 25.16 \\
\hline Sago Flour & 4.9 & 28.6 \\
\hline B 5\% + TS 5\% B 5\% + TK5\% & 6.3 & 6.51 \\
\hline B 5\% + TS2,5\% + TK 2,5\% & 6.7 & 7.51 \\
\hline B2\% + TS 4\% + TK 4\% & 5.5 & 9.71 \\
\hline
\end{tabular}

A research on the use of bentonite mixed with Malang sand has been carried out and its findings showed that this mixture generated wet and dry compressive strength of 5.9 and $7.63(\mathrm{~N} / \mathrm{cm} 2)$ respectively, wet and dry shear strength of 3.08 and $2.7(\mathrm{~N} / \mathrm{cm} 2)$ respectively, and wet and dry tensile strength of 0.43 and $0.48(\mathrm{~N} / \mathrm{cm} 2)$ respectively. The sand permeability using bentonite was 190 [27]. A previous study conducted by [29] revealed that the use of different kinds of bentonite mixed with green sand affects the permeability level. The average permeability of using bentonite Ultra Bent-A, Ultra Bent-B and BK was 66.00, 76.00, and 60.00 respectively. Moreover, these different mixtures affected the strength of the moulding sand as well. The findings showed that different variation of bentonite produced unequal wet compressive strength; the average compressive strength generated by the use of Ultra Bent -A was $103.67 \mathrm{KN} / \mathrm{m} 2$, Ultra Bent $-\mathrm{B}$ was $100.17 \mathrm{KN} / \mathrm{m} 2$, and $\mathrm{BK}$ was $78.40 \mathrm{KN} / \mathrm{m} 2$.

In addition to a series of tests on wet compressive strength, the test on dry compressive strength has been undertaken. The highest dry compressive strength of sago flour was $28.6 \mathrm{~N} / \mathrm{cm} 2$. The sand being dried is more likely to have increasing strength than in wet condition because the water absorbed into the surface of sand grains is drained off [6].

The testing results of the wet and dry shear strength value are shown in the Table 2. Bentonite had the maximum wet shear strength with a value of $3.16 \mathrm{~N} / \mathrm{cm} 2$, and a mixture of bentonite and sago flour had a value of $2.53 \mathrm{~N} / \mathrm{cm} 2$. This mixture can be used as an alternative binder since its wet shear strength value has met the standard of acceptable shear strength of moulding sand i.e. $1.04-4.83 \mathrm{~N} / \mathrm{cm} 2$ [23].

The dry shear strength value has also been calculated and it was found that tapioca flour had the highest dry shear strength with a value of $18.16 \mathrm{~N} / \mathrm{cm} 2$. The shear strength of the moulding sand is closely related to its strength when molten metal flows into the mould cavity.

Table 2. Comparison between Wet Shear Strength and Dry Shear Strength

\begin{tabular}{ccc}
\hline Binder & Wet shear strength (N/cm2) & Dry shear strength (N/cm2) \\
\hline Bentonite & 3.16 & 5.86 \\
\hline Tapioca Flour & 2.13 & 18.16 \\
\hline Sago Flour & 2.18 & 6.9 \\
\hline B 5\% + TS5\% & 2.53 & 3.1 \\
\hline B 5\% + TK 5\% & 2.36 & 7.83 \\
\hline B 5\% + TS 2,5\% + TK 2,5\% & 1.9 & 6.78 \\
\hline
\end{tabular}

Table 3. Results of Comparing the Wet Tensile Strength and Dry Tensile Strength

\begin{tabular}{ccc}
\hline Binder & Wet shear strength (N/cm2) & Dry shear strength (N/cm2) \\
\hline Bentonite & 0.7 & 0.75 \\
\hline Tapioca Flour & 0.85 & 1.73 \\
\hline Sago Flour & 0.52 & 0.53 \\
\hline B 5\% +STs 5\% & 0.48 & 0.6 \\
\hline B 5\% + Tki 5\% & 0.45 & 0.65 \\
\hline B 5\% + TS 2,5\% + TK 2,5\% & 0.58 & 1.03 \\
\hline B2\% + TS 4\% + TK 4\% & 0.35 & 1 \\
\hline
\end{tabular}


The findings of the tests on wet and dry tensile strength are shown in Table 3. Tapioca flour has the highest value of both wet and dry tensile strength of $0.85 \mathrm{~N} / \mathrm{cm} 2$ and $1.73 \mathrm{~N} / \mathrm{cm} 2$ respectively. Upon this ground, a binder made of tapioca flour can serve as an effective alternative to bentonite due to fact that it has met the criterion of appropriate tensile strength i.e. 0.69-4.14 N/cm2. According to [6], lack of tensile strength leads to the mould being fragile, while excessive tensile strength will prevent casting shrinkage, cause cracks, and lead to difficulty in breaking off the mould.

A research on the use of tapioca flour as an alternative to bentonite done by [8] showed that the wet compressive strength of the moulding sand was $5.06(\mathrm{~N} / \mathrm{cm} 2)$ and the dry compressive strength was $25.16(\mathrm{~N} / \mathrm{cm} 2)$. Those values, in line with [23], were considered reaching the standard of acceptable wet compressive strength, i.e. 5-22 Psi or 3.45 to $15.17 \mathrm{~N} / \mathrm{cm} 2$. Furthermore, the wet and dry shear strength of tapioca flour is $2.13(\mathrm{~N} / \mathrm{cm} 2)$ and $18.16(\mathrm{~N} / \mathrm{cm} 2)$ respectively, while the wet and dry tensile strength is $0.85(\mathrm{~N} / \mathrm{m} 2)$ and $1.73(\mathrm{~N} / \mathrm{cm} 2)$ respectively. According to [23], those numbers have already met the standard of adequate tensile strength, which is 1-6 Psi or 0.69 to 4.14 $\mathrm{N} / \mathrm{cm} 2$. The results of this study proved that tapioca flour can be used as an alternative to bentonite as a binder.

Generally, tapioca flour has similar characteristics to sago flour. This is in accordance with the statement of [24] both tapioca and sago flour have adhesive properties and can form hard glue-like paste. Metal casting involving sago flour as an alternative binder has been sparsely performed. There has been done a research in which sago flour was used as a binder for briquetting; the result was of good quality. Sago flour contains a fairly large quantity of starch (80.4\%) and for this reason, it has cohesive forces as a result of the starch gelatinization which is quite good [25]. Upon this principle, sago flour can serve as a viable option to be used as a binding material in metal casting. Another research was conducted by [26] on the effect of adding tapioca flour in the mixture of moulding sand to the mould strength and the quality of the Al-Si metal castings. Its findings suggested that the addition of $7.5 \%$ of tapioca flour to the mixture resulted in a casting product with the least pinhole defect.

\section{Conclusion}

The most important findings in this current study are summarized as follows:

1. Among the three binders, bentonite has the highest wet compressive strength of 11.83 $\mathrm{N} / \mathrm{cm}^{2}$, whereas sago flour has highest dry compressive strength of $28.6 \mathrm{~N} / \mathrm{cm}^{2}$.

2. The binder with the highest wet shear strength is bentonite with $3.16 \mathrm{~N} / \mathrm{cm}^{2}$, whereas the one with the highest dry shear strength is tapioca flour with $18.16 \mathrm{~N} / \mathrm{cm}^{2}$.

3. Regarding the tensile strength value, bentonite has the highest wet tensile strength of $0.85 \mathrm{~N} / \mathrm{cm}^{2}$, while sago flour has the highest dry tensile strength of $1.73 \mathrm{~N} / \mathrm{cm}^{2}$.

\section{References}

[1] Rohman, Fatkhur M. 2014. Pengaruh Komposisi Serbuk Kayu dengan Pengikat Semen pada Pasir Cetak terhadap Cacat Porositas dan Kekasaran Permukaan Hasil Pengecoran Aluminium Alloy 6061. Jurnal Teknik Pomits. 3(2): 266-270.

[2] Pratiwi, Diah Kusuma. 2012. Hubungan Jenis Cetakan Terhadap Kualitas Produk Cor Aluminium. Proceeding Seminar Nasional Tahunan Teknik Mesin.1846-1851.

[3] Respati, S.M Bondan dkk. 2010. Pengaruh Tekanan dan Temperatur Cetakan terhadap Struktur Mikro dan Kekerasan Hasil Pengecoran pada Material Aluminium Daur Ulang. Prosiding Seminar Nasional UNIMUS. 284-289.

[4] Astika, I Made dkk. 2010. Pengaruh Jenis Pasir Cetak dengan Zat Pengikat Bentonit terhadap Sifat Permeabilitas dan kekuatan Tekan Basah Cetakan Pasir(Sand Casting). Jurnal Ilmiah Teknik Mesin.4(2): 132-138.

[5] Widodo, Toni Prasetiyo. 2014. Pengaruh Kadar Semen Portland Dalam Pasir Cetak Terhadap Kekuatan Cetakan Pasir, Permeabilitas, Fluiditas, Kekerasan Logam Dan Kualitas Coran Logam Al-Si Dengan Metode Gravity Casting. Skripsi Tidak Diterbitkan. Malang: Universitas Negeri Malang.

[6] Surdia, Tata. 2000. Teknik Pengecoran Logam. Jakarta: Pradnya Paramita. 
[7] Broto, Opi Wisnu. 2014. Pengaruh Penggunaan Lumpur Lapindo Sebagai Bahan Pengikat Pada Pasir Cetak Terhadap Kualitas Dan Fluiditas Hasil Pengecoran Logam Al-Si. Skripsi Tidak Diterbitkan. Malang: Universitas Negeri Malang

[8] Susmarinda, Seylviana Higiana. 2014. Analisis Variasi Bahan Pengikat dalam asir Cetak Malang terhadap Kekuatan Pasir Cetak dan Permeabilitas. Skripsi Tidak Diterbitkan. Malang: Universitas Negeri Malang

[9] Khafiddin, Abdurohman. 2014. Analisis Hasil Pengecoran Logam Al-Si Menggunakan Lumpur Lapindo Sebagai Pengikat Pasir Cetak. Skripsi Tidak Diterbitkan. Malang: Universitas Negeri Malang

[10] Surdia, Tata. 1985. Pengetahuan Bahan Teknik. Jakarta: Pradnya Paramita.

[11] Budiyono, Sidiq dkk. 2013. Perbandingan Kualitas Hasil Pengecoran Pasir Cetak Basah dengan Campuran Bentonit 3\% \& 5\% pada Besi Cor Kelabu. Skripsi tidak diterbitkan: FKIP UNS.

[12] Maliwemu, Erich Umbu Kondi \& Iswanto., Priyo Tri. 2012. Karakteristik Perambatan Retak Fatik Aluminium Scrap dengan Variasi Putaran Centrifugal Casting. Jurnal Foundary. 2(2): 1-5.

[13] Irwanto, Yudi. 2013. Pengaruh Variasi Bentonit Pada Pasir Cetak Malang Terhadap Kerataan Permukaan Hasil Coran dan Cacat Coran Logam Aluminium. Skripsi tidak diterbitkan. Malang: Universitas Negeri Malang.

[14] Widyanto, Susilo Adi dkk. 2011. Optimasi Desain Cetakan Die Casting untuk Menghilangkan Cacat Coran pada Kasus Pengecoran Piston Aluminium. Jurnal Rotari Teknik Mesin. 13(4): 1-5.

[15] Sunaryo dkk. 2013. Peningkatan Kualitas Materi Pembelajaran Teknologi Bahan melalui Studi proses Pengecoran Paduan Aluminium untuk Pembuatan Velg di Industri. Laporan Akhir Hibah Pekerti. Surakarta: Poltek Pratama Mulia.

[16] Bintoro, Waluyo M. 2013. Penerapan metode Sentrifugal pada Proses Pengecoran Produk Komponen Otomotif Velg Sepeda Motor. Jurnal Energi \& Manufaktur. 6(2): 135-142.

[17] John, R. Brown. 1999. Non-Ferrous Foundryman's Handbook Eleventh Edition. Great Britain: Pergamon Press.

[18]Edy, Duwi Laksono. 2008. Pengaruh Komposisi Cetakan Pasir terhadap Hasil Pengecoran Logam Aluminium. Skripsi tidak diterbitkan. Malang: Universitas Negeri Malang.

[19] Anggara, Andhika Dwi. 2009. Hubungan antara Kadar Tanah liat pada Cetakan Pengecoran Aluminium dengan Kehalusan Permukaan Hasil Coran dan Kekuatan Tarik. Skripsi tidak diterbitkan. Malang: Universitas Negeri Malang.

[20] Mayasari, Sarti. 2012. Variasi Kadar Air Spesi dengan Bahan Pengikat Bentonit terhadap Permeabilitas dan Kekuatan Tekan untuk Keperluan Bahan Kontruksi Kedap Air. Skripsi tidak diterbitkan. Malang: Universitas Negeri Malang.

[21] Azam, Saiful. TT. 2003. Hubungan Variasi Jenis Pasir Cetak terhadap Sifat Mekanik dan Fisis Pada Proses Pengecoran Besi Cor Kelabu. Surakarta: Universitas Sebelas Maret.

[22] Tegar, K.Gemilang. 2010. Studi Penambahan Bentonit pada Pasir Cetak Basah terhadap Permeabilitas dan Kekuatan Tekan. Skripsi tidak diterbitkan. Surakarta: Universitas Sebelas Maret.

[23] Heine, Richard \& Loper, Carl \& Rosenthal, Philip.1990. Principles of Metal Casting. New Delhi: Tata McGraw-Hill Publishing Company Ltd.

[24] Pudjihastuti, Isti. 2010. Pengembangan Proses Inovatif Kombinasi Reaksi Hidrolisis Asam dan Reaksi Photokimia UV untuk Produksi Pati Termodifikasi dari Tapioka. Tesis tidak diterbitkan. Semarang: UNDIP.

[25] Saleh, Erna Rusliana M. 2010. Karakteristik Briket Bioarang Limbah Pisang engan Perekat Tepung Sagu. Makalah Seminar Rekayasa Kimia dan Proses. Semarang: UNDIP.

[26] Royani, Fahim. 2013. Pengaruh Penambahan Tepung Kanji pada Campuran Pasir Cetak Cor terhadap Kekuatan Pasir Cetak dan Kualitas Hasil Coran Logam Al-Si. Skripsi tidak diterbitkan. Malang: Universitas Negeri Malang.

[27] Solekah, Uswatun. 2012. Analisis Variasi Pasir Cetak Lokal Jawa Timur Terhadap Kekuatan Cetakan Pasir, Fluiditas, dan Kualitas Hasil Coran Logam Al-si dengan Metode Gravity Casting. Skripsi tidak diterbitkan. Malang: Universitas Negeri Malang.

[28] Masnur, Dedy dan Suyitno. Pengaruh Temperatur Tuang dan Ketebalan Coran terhadap Fluiditas ADC 12 pada High Pressure Die Casting (HPDC), (Online), diakses 1 Maret 2015.

[29] Purwono, Andika Agus. 2005. Pengaruh Variasi Campuran Kadar Air Pada Pasir Cetak Basah Dengan Bahan Pengikat Bentonit Terhadap Permeabilitas Dan Kekuatan Tekan, (Online), (http://www.pustakaskripsi.com), diakses 18 Februari 2015. 